УдК $\quad$ 94:343.352(497.1)"1945/..."

DOI https://doi.org/10.31212/tokovi.2021.3.buc.89-120

Оригинални научни рад

Примљен: 27.2.2021.

Прихваћен: 12. 11. 2021.

Klaus BUCHENAU

University of Regensburg

klaus.buchenau@geschichte.uni-regensburg.de

\title{
The Third Path into the Twilight? Corruption in Socialist Yugoslavia
}

\begin{abstract}
Corruption in socialist Yugoslavia was a specific phenomenon when compared to the inter-war period or to post-socialism. In contrast to liberalism, communist ideology did not support an understanding of corruption as a problem of its own but tended to see political and material "deviations" as originating from the same root - i.e., from a lack of political morale. The League of Communists failed to live up to its role as an educator of society, since it was trapped between declarative moral rigorism and the fact that material need and greed could be satisfied best by becoming a party member.
\end{abstract}

KEY WORDS: corruption, Yugoslavia, Serbia, communism, clientelism

Corruption is a major issue in the successor states of Yugoslavia. It is often treated as an obstacle to "Europeanisation," while progress in the fight against corruption is viewed as a step on the road to Europe. Up until now, the historical aspect has been largely neglected in this discourse either because there is little interest in it or as a result of extreme simplifications: some authors view socialism as a "school of informality", where the bypassing of formal procedures was perfected, where mistrust of the state flourished, a culture of hidden activities and party partisanship developed, and where, not least, there was a constant hunger for resourc- 
es which could not be satisfied legally. ${ }^{1}$ Others see in socialism a positive contrast to the chaotic years of post-communism and stress that order and rules still prevailed here, but then imploded, creating broad scope for all kinds of manipulation, including corruption. ${ }^{2}$ They focus on mechanisms in post-communism itself, to which a power and value vacuum, economic deprivation, and, in the case of Yugoslavia, factors such as a warlord economy and a sanctions-based smuggling economy are also attributed. There have also been attempts to combine both views, for example the political scientists Wayne Sandholtz and Rein Taagepera, who contend that while communism was indeed a school of corruption, only the chaos and the breakdown of institutions after its fall caused the much deplored corruption phenomena of post-socialism. ${ }^{3}$

What is usually overlooked in this search for the roots of post-communist corruption is the historical dimension of the topic itself. This is in no way meant as an insinuation here: no longue durée of corruption or even a "typical Balkan" corruption is to be proven here; rather, the aim is to show, against the background of a general and theoretical interest, whether and how corruption has changed over time-in terms of practices, but also in terms of the understanding of corruption. The socialist period is ideally suited for this goal because rarely has a change of power been associated with such profound systemic changes as it was when communist regimes were installed and dismantled. At the same time, even the agents of the most radical change, such as the new rulers in 1945 or 1989 , had to take certain social aspects into account in order to be able to consolidate their rule at all. Against this backdrop, this article attempts to sketch out the corruption problems in socialist Yugoslavia. As a whole, it is to be viewed as a work in progress; it is related to a larger research project: a historical long term study of the history of corruption in Serbia

1 So, for example: Mancur Olson, Power and prosperity. Outgrowing communist and capitalist dictatorships, (New York: Basic Books, 2000).

2 See the theoretical model of Andrei Shleifer and Robert W. Vishny, according to whom a functioning pyramid of power (such as the communist one) leads to lower and less frequent bribes than a weak system (as in many post-communist states during the 1990s) in which every institution can decide to institute its own bribery schemes. Cf. Andrei Shleifer, Robert W. Vishny, "Corruption", The Quarterly Journal of Economics, Vol. 108, No. 3, 1993, 599-617. For an illustrative empirical study of Russia's transformation during the late 1980s and early 1990s, cf. Vadim Volkov, Violent entrepreneurs. The use of force in the making of Russian capitalism, (Ithaca: Cornell University Press, 2002).

3 Wayne Sandholtz, Rein Taagepera, "Corruption, Culture and Communism", International Review of Sociology, Vol. 15, No. 1 (2005), 127. 
and Croatia. ${ }^{4}$ Thus, the focus of this article is, but not limited to, Serbia, as I conducted research in the Arhiv Srbije as well as in the Arhiv Jugoslavi$j e$, examples from the federal level and from other Yugoslav republics are also mentioned.

\section{The Socialist Corruption Discourse}

On the legislative level, Tito Yugoslavia behaved similar to western states. This means: our understanding of corruption today as "abuse of entrusted power for private gain" ${ }^{5}$ was not directly reflected in the laws of the country. Thus, there was no criminal offense named corruption; the word did not appear in the Criminal Codes of 1952 or 1976. Socialist legal specialists appear to have agreed with their Western liberal colleagues that the word "corruption" was simply too vague to be included in the range of legal offenses.

Instead, as is still the case today in most national legislations, the phenomenon was "translated" into different concrete practices, which were then explicitly criminalized. Thereby, the Belgrade Ministry of Justice, which was dissolved in 1953 and dispersed across other ministries, also engaged in systematic comparative law. When the "Law on Crimes against the National Economy" was drafted in 1946, it was based not only on the Soviet model, but also drew on examples from the bourgeois democracies of the interwar period. ${ }^{6}$ The Yugoslav Criminal Code from 1952 recognised the offence of passive and active bribery (Article 325/326), of peculation (Article 322), of acceptance of benefit (Article 314) and of unlawful mediation (324). In all of these legal constructions, it was assumed that a state representative had both broken formal rules and received a benefit for doing so. Thus, these criminal offenses clearly fall under our current perception of corruption, which has been largely shaped by actors such as Transparency International or the World Bank. An article concerning "improper official conduct" (Art. 317) was also introduced. In a broader sense, such offenses also can be listed, which not necessarily, but

4 For a description of the research project, see: https://www.uni-regensburg.de/ forschung/geschichte-der-korruption-in-suedosteuropa/dfg-projekt-von-derinformalitaet-zur-korruption-1817-2018-serbien-und-kroatien-im-vergleich/ index.html (access date 25 February 2021).

5 The well-known definition from Transparency International. Available online at: https://www.transparency.org/en/what-is-corruption, (access date 25 February 2021).

6 Arhiv Jugoslavije (AJ), Fond Ministarstvo pravosuđa Vlade FNRJ (49), 26, Nacrt za Zakon o krivičnim delima protiv narodne privrede. 
could also be committed by state officials exploiting the power entrusted to them: speculation (Article 233), theft (249), embezzlement (254), fraud (258), extortion (261). ${ }^{7}$ The Federal Criminal Code of 1976 contains somewhat different categorizations, more differentiated for public servants; however, the principle of the legal "translation" of corruption into concrete practices remained the same. The focus is on the "acceptance of bribes" (Article 179), where it has now been made clear that the advantage granted is usually of a material nature (money or gifts), but may also be of another kind. In addition, "abuse of official position" (Article 174), "disloyalty in service" (175), "fraud in service" (176), "theft in service" (177), misappropriation in service (posluga u službi, 178), unlawful mediation (180), breach of law by a judge (181), unlawful confiscation and disbursement (185) are punishable. ${ }^{8}$

The principle applied that abuses of office out of personal material interest weighed particularly heavily. This can be seen, for example, in the 1945 "Law on the Defence of People's Property and its Administration". For irresponsible handling of such property, 1-3 years of ordinary imprisonment were stipulated; for disposal for personal gain, 2-5 years of severe imprisonment; and for the transfer of state property to private individuals in exchange for a bribe, 2-6 years of severe imprisonment. ${ }^{9}$ The 1948 "Law on Crimes Against the People's Property and the Property of Cooperatives and Other Social Organizations" also stipulated particularly severe punishments for cases in which manipulation was motivated by greed for gain. ${ }^{10}$ The Yugoslav Ministry of Justice also took the position that a socialist state had to protect social property because, unlike under capitalism, it represented the economic basis of the entire system. ${ }^{11}$

However, one should not stop at observing legal similarities between the East and the West - because law as such had a very special position in socialist states. It did not claim, as in liberal systems, to be enthroned above society as an arbitrator and to see to it that the conflicts arising from social plurality were resolved peacefully and in accordance

$7 \quad$ The Yugoslav Criminal Code of 2. March, 1951, Translated into German with an introduction by Dr. August Munda, (Berlin, 1952).

8 Krivični zakon Socijalističke Federativne Jugoslavije, (Zagreb, 1982).

9 Zakon o zaštiti narodnih dobara i njihovom upravljanju, Službeni list 1 (1945), 36, 296.

10 Zakon o krivičnim delima protiv opštenarodne imovine i imovine zadružnih i drugih društvenih organizacija, Službeni list 4 (1948), 87, 1365-1366.

11 AJ, 49-26, Krivična dela protiv lične i privatne imovine (1946), 4. 
with the law. ${ }^{12}$ Instead, the law occupied a hybrid position between the ideological goals of the party, which were also state goals, and the legal traditions in the narrower sense, for example, observance of rules and procedural correctness. More than in liberal systems, the law was subordinated to the primacy of politics.

Thus, socialist Yugoslavia saw itself first and foremost as the scene of revolutionary transformation, not as a guarantor of correct procedures. This was especially true for the first years of the state when allegations of corruption were regularly intermingled with accusations of having collaborated with the Axis powers and of being an "enemy of the people" in general. ${ }^{13}$

The ideal-typical bureaucracy of Max Weber ${ }^{14}$ found no support in Yugoslav discourse - the words "bureaucracy" (birokratija) and official (činovnik) had too much of a negative connotation. Civil service and professional honour, which in the discourse in and about Prussia were so highly praised as a remedy against corruption, ${ }^{15}$ were associated with violations of equality and the return of the class enemy, not with ethos and professionalism. Birokratija and činovnik (from Slav. čin, meaning here: 'rank') sounded like hierarchy, separation from the people, arrogance, and unfair privileges. This had already been latent in the first Yugoslavia, but just latent - činovnik in particular was often used in a neutral way in the newspapers of the interwar period, not as a swear word. ${ }^{16}$ In the communist discourse, on the other hand, one spoke of government or administrative organs (organi vlasti/uprave) as well as službenici (from služba = service), which can mean both employee and official and blurred the dis-

12 Friedrich von Halem, „Eine Skizze über Gesetz und Wertordnung in Ost und West: Von der Antike bis zur Moderne", Forum für osteuropäische Ideen- und Zeitgeschichte, Vol. 7, No. 1 (2003), 15-51.

13 Cf. Aleksandar Đ. Marinković, „Uništenje srpske privredne elite posle Drugog svetskog rata - Primer porodice Teokarović", Istorija 20. veka 2/2010, 135-148; Srđan Cvetković, „Afera 'Granap ' - smrtna kazna zbog korupcije“, Korupcija i razvoj moderne srpske države, eds Aleksandra Bulatović, Srđan Korać, (Beograd: Centar za menadžment, 2006), 143-150.

14 Max Weber, Wirtschaft und Gesellschaft, (Tübingen: Mohr 1922), 650-678.

15 This image, which was shaped not least by the Bielefeld school of social history, has, however, been considerably battered in the last decade by young researchers with a cultural-historical orientation. See, for example: Patrick Wagner Bauern, Junker und Beamte. Lokale Herrschaft und Partizipation im Ostelbien des 19. Jahrhunderts, (Göttingen: Wallstein-Verlag, 2005).

16 Even positive connotations were possible: for example, in a reader's letter to the Niške novine of 26.2.1933 it says: "In terms of his moral qualities, the činovnik must be a role model for others." 
tinction between the two categories. Typical of this hostility to differentiation is, for example, a statement made by the leading Montenegrin communist Veljko Zeković (1906-1985), who stated in a meeting in 1959:

"I think our political organisations should put all their efforts into integrating our službenici, who implement the laws today, more deeply into our socio-political system to make sure that they have less chance of turning into a činovnik, as happens to some people, often through no fault of their own." ${ }^{17}$

Furthermore, a corrupt public servant was viewed as an enemy, but not as the biggest enemy. That this status was ultimately reserved for political opponents of the Yugoslav socialist projects can be seen in the handling of speculation on the one hand and sabotage on the other. In 1946, following a short phase of indiscriminately harsh legal persecution, ${ }^{18}$ a distinction was made between profit-oriented speculation and politically oriented sabotage; only for the latter a death sentence could be imposed in peace times. ${ }^{19}$

The primacy of the collective over the individual, as well as revolutionary asceticism, gave rise to a negative valuation of corruption; this negative valuation could draw, albeit rather covertly, on the tradition of modern statehood, which, throughout Europe, attempted to impose generally binding notions of proper official conduct and was extremely critical of enrichment in service. However, there were also strong reasons in socialist Yugoslavia to play down the problem. On the one hand, like other social problems, corruption was viewed as a legacy of the past that would disappear on the road to the perfect socialist society. Societal criticism that was not satisfied by these promises was filtered so that a truly open discourse on corruption could not develop - although criticism of the abuse of power by senior party officials certainly played a role in the student movement of $1968 .{ }^{20}$ Above all, however, the primacy of ideology and politics had the effect that the problem was interpreted in ideological-political terms, and it was compressed into concepts that inextricably linked corruption with other deviations from the communist ideal.

17 AJ, Fond Savez komunista Jugoslavije/Komisija za kadrove (507/XIII), 7/4, Stenografske beleške sa sastanka Komisije za kadrove CK SKJ, 29. 6. 1959, 4.

18 Zakon o suzbijanju nedopuštene spekulacije i privredne sabotaže, Službeni list 1 (1945), 26, $\S 3$ and 4.

19 Zakon o suzbijanju nedopuštene trgovine, nedopuštene špekulacije i privredne sabotaže, Službeni list 2 (1946), 56, $§ 4$ and 6.

20 Boris Kanzleiter, Die "Rote Universität". Studentenbewegung und Linksopposition in Belgrad 1964-1975, (Hamburg: VSA Verlag, 2011). 
This can be seen particularly clearly in the files of the Central Committee (CC), especially its Commissions for Ideology and for Cadre Development. Corruption was hardly mentioned; instead, the problem was discussed in nebulous terms like "deformation", "deviation", "negative manifestations". These terms summed up what was understood as disloyalty to the party, straying off the right path - "false" political views, differences between words and actions, an "uncommunist" way of life, material greed and, last but not least, abuse of authority. For example, for a work group from the League of Communists of Serbia, the problem in 1978 was as follows:

"As a result of the advance of liberalism in the Union of Communists of Serbia and above all in the leadership in 1971 and especially in 1972, there were increasingly massive outbreaks of technobureaucracy and managerial relationships, to increasingly large transfers and misappropriation of proceeds from direct production to the spheres of commerce, banks and institutions. Favourable conditions have been created for the uncontrolled use of large resources by small groups and individuals, who often, on different grounds, but mainly by means of estranged representations and individuals with dubious pasts, are linked with foreign, politically as well as financially dubious companies. There was a reasonable suspicion that Yugoslav capital had been illegally transferred abroad, although the motives were also of a broader political nature: undermining the economic foundations of society and compromising self-management. In this project, technocrats, liberals, Inform Bureau supporters, the forces defeated at the IV Plenum, remnants of the class enemy, political émigrés, etc. found a common interest." 22

The blurred world of terminology in which lawbreaking, political and moral accusations came together turned economic criminals into political enemies and political enemies into economic criminals. On the one hand, this was specifically communist, especially when compared with the interwar period, where talk of corruption usually referred to concrete social practices that were primarily attributed to the human pursuit of gain and not to the political sphere as such. But, on the other hand, it was not a total break, for in the 1920s and 1930s, there had also been a strand of discourse that placed corruption in a very broad context, as-

21 AJ, 507: Ideološka komisija (VIII); Komisija za razvoj i kadrovsku politiku (XIII).

22 Arhiv Srbije (AS), Fond Savez komunista Srbije (Đ-2), k. 89, f. 104, Izveštaj Radne Grupe Izvršnog Komiteta Predsedništva CK SKS o problemima nastalim u ostarivanju akcije „Vrh”, Beograd, Oktobar 1975. 
sociating it, for example, with cultural decay, a lack of patriotism, and a lack of faith in God.23

The socialist "all-round terms" were used by competing groups within the party. On the one hand, there was the dogmatic discourse, to which older communists from the partisan generation belonged. For the most part, they did not directly criticise the 1950s and 1960s reforms but harboured concerns about a system that they believed was becoming more and more confusing, making it more difficult to rule firmly and enabling egoism at the expense of the general public. Added to this was a generational component: according to some of the older comrades, deformation, deviation etc. were strongly related to the rejuvenation of the party, that is, with the admission of members who no longer shared the initiatory experience of the partisan struggle and were therefore supposedly less heroic and ascetic and, instead more pragmatic, technocratic, ${ }^{24}$ and opportunistic. Opportunists in particular, who only joined the party to advance their career, were criticised for being of weak character. A typical example of this line of thinking was Jure Bilić (1922- 2006), one of the organisers of the resistance movement in Croatia during WWII. At a meeting of the federal Central Committee Commission for Cadre Policy in 1976, he railed that during the war, one could lose one's head for party membership, but that now people joined the party to get cars, apartments, and televisions. According to Bilić, this "petit bourgeois" behaviour was closely linked to the transformation of Yugoslav society into a socialist market economy. Bilić saw the prestige of party membership fall into decay since it was associated with the pursuit of a higher standard of living but "without commitment, without work, without struggle [...] In other words, there are people who join the party in order to realize its agenda, and there are those who want to secure privileges that were only made possible by [socialist] social development." ${ }^{25}$

On the other hand, another camp criticised the excessive privileges, nepotism, and enrichment of the partisan generation. This position was

23 Klaus Buchenau, „Korruption im ersten Jugoslawien (1918-1941). Eine Skizze zu Diskurs und Praxis", Südost-Forschungen 72/2013,130-164.

24 Regarding the meaning of this term, a 1959 Ideological Commission protocol states, "The class of technocrats also represents younger professionals who do not align their interests with the interests of the community and therefore use current conjunctural opportunities to satisfy their interests.” AJ, 507/VIII, II/4-a-27, k. 21, Stenografske beleške sa sastanka radne grupe koja proučava teze „Komunisti u preduzeću”.

25 AJ, 507/XXX, k. 22, Sednica komisije za razvoj SKJ i kadrovsku politiku, Beograd, 11. 6. 1976, 76 . 
also represented at the meeting mentioned above, by a comrade identified as St. G., who cited a statistic according to which 17-18 percent of Yugoslavia's major criminals were party members and complained about the "old partisan families, the old communist or privileged families" who occupied important positions and did not give the millions of new citizens any opportunities for advancement. He continued: "In certain milieus, there are still thugs, thieves, who compromise the party and should be thrown out". ${ }^{26}$ Behind the confrontation between the two camps was, not least, the struggle for jobs. This intensified at the end of the 1950s, when the post-partisan generation aspired to positions, but now and then came up against a "glass ceiling." ${ }^{27}$

These two camps were not equally influential. The central position of the National Liberation Struggle in the public memory as well as the generally easy access to resources for war veterans meant that the older camp was predominant, especially up until the fall of the Minister of the Interior Aleksandar Ranković in 1966. In the centralized, largely intelligence-driven system of early Tito-Yugoslavia, war cadres were in charge, and they had a strong tendency to contest the necessary strength of character in younger Communists. The party itself was also at least partially aware of the problem. In November 1963, for instance, the Ideological Commission of the League of Communists of Yugoslavia lamented: "People usually talk to the young people about the revolution one-sidedly, and the revolution is usually reduced to its armed aspect. This creates an inferiority complex amongst the youth." Young people should be made aware that the revolution continues: "They have to be much more aggressive in attacking certain negative phenomena - careerism, protectionism, abuses of office, crime, etc." 28

Following the overthrow of Ranković, the hitherto frequent mixture of criticism of corruption and Stalinist dogmatic elements was apparently no longer as convincing. Communists, who raised accusations of corruption against the modern "managerial types" in the party, were in some cases no longer listened to. For example, the party rejected petitions from former UDBA employee Milisav Jovanović, who made serious accusations in 1969/70 against two senior Serbian party officials and complained to Tito that the League of Communists of Serbia was protecting

26 Ibid., 83-84.

27 AJ, 507/XIII, K-7/4, Informacija o kadrovskim problemima koji su tretirani na republičkim kongresima Saveza komunista, 6. 10.1959, 5-6.

28 AJ, 507-39, V-4a/4, Diskusija o materijalu za referat za Plenum CK SKJ, 21. 11. 1963. 
the comrades in question. Latinka Perović portrayed the complainant to Tito's cabinet as a troublemaker, and the matter was apparently shelved. ${ }^{29}$

In this respect, the party file of UDBA agent Njegoslav Pantelić is also interesting. Pantelić belonged to those members of the security apparatus who viewed the "managerialisation" of the communist party with deep mistrust and had little sympathy for liberal freedoms. In 1972, together with two other UDBA staff members, he set up a working group dedicated to fighting white-collar crime and corruption. They planned an operation called Akcija Vrh (Action Summit), which might indicate that the focus was not on petty but on grand corruption. For the party leadership, which had set up the working group in the course of its clampdown on the "Serbian liberals," the group went too far; it was soon accused of researching too broadly and too unprofessionally and of "fabricating" material, of compromising honourable comrades using false information. In particular, the corruption fighters demanded that the Serbian leadership cooperate more closely with the federal authorities and the authorities of other Yugoslav republics in order to fight crime more effectively. In 1973, the group was disbanded, and its members, Pantelić in particular, now accused the Serbian leadership of protecting organized crime. Pantelić was eventually expelled from the party, although the file leaves many questions unanswered - which could probably only be answered by examining the UDBA documents. ${ }^{30}$

\section{Corrupt Practices}

Direct accusations of bribery were relatively rare in socialist Yugoslavia. However, accusations of corruption were almost ubiquitous, i.e., nepotism, clientelism, abuse of power to obtain various goods. In the files of both the League of Communists and the Socialist Alliance, ${ }^{31}$ two resources were particularly at issue, and they were as vital as they were scarce and therefore particularly coveted: housing and jobs.

A fundamental problem was the distinction between legitimate, politically desirable privileges on the one hand and abuses on the other.

29 See the collected documentation in: AS, Đ,-2, k. 4.

30 AS, Đ-2, k. 89, f. 104.

31 See, for example, the annual report of the Complaints Commission of the Presidium of the Republic Conference of the Socialist Alliance of the Working People of Serbia for 1976/77: AS, Fond Republička konferencija SSRN Srbije (Đ-75), k. 298, Izveštaj o radu Komisije predsedništva RK SSRN Srbije za predstavke i žalbe u periodu januar 1976-jun 1977 godine, 22.9.1977. 
This question was particularly pertinent when dealing with members of the Communist Party. The CC Commissions for Ideology and Cadre Policy were torn when it came to prescriptions against abuse of office. On the one hand, party members were considered per se to be political and moral leaders in society, so abuses were readily responded to by calling for (even) more Communists, especially in leadership positions. This strategy was advocated, for example, by Asllan Fazlija, a member of the Federal Executive Council, at a meeting of the Cadre Commission in 1976. At present, according to the Kosovar functionary, only 60.9 percent of the positions in the federal bodies are held by party members, but this is not enough to "fight corruption and the abuse of office and authority. "Membership in the League of Communists can be an indicator for assessing the political determination and maturity of the federal administration [...]". ${ }^{32}$ On the other hand, the party was fully aware that it had itself taken on the characteristics of a clientelist rope team and that the party membership card could by no means be regarded as proof of strength of character. This was evident, for example, from internal party statistics on party expulsions. In the first half of the 1970s, the proportion of expulsions for economic misdemeanours and abuse of office increased - from 9.51 percent in 1972 to 17.3 in 1975 . Due to the political calm during this period, expulsions declined overall. Therefore, the absolute increase (1972: 1092, 1975: 1341) was far from dramatic - but subjectively, abuse of office became an increasingly important issue for the party. This was especially true for the Yugoslav People's Army, where in 1975 criminality, at 37.1 percent, even advanced to the second most important reason for exclusion after "political irresponsibility" (49.6 percent)..$^{33}$

Party expulsions were not a simple matter. The Cadre Commissions observed with concern that - with the exception of the major purges, such as in 1971/72 - the expulsions mainly affected workers, against which leadership cadres often successfully defended themselves by appealing against the proceedings of the local Statutory Commission, using the support of higher-level networks. ${ }^{34}$

\section{Ibid.}

33 AJ, 507/XIII, k-30/12, Statistički pregled Saveza komunista Jugoslavije za 1972. godinu, 1. 12. 1973; AJ, 507/XIII, k-30/13, Statistički pregled Saveza komunista Jugoslavije za 1973 godinu, 1. 8. 1974; AJ, 507/XIII, k-30/17, Statistički pregled Saveza komunista Jugoslavije za 1975 godinu, 1.12.1975.

34 Regarding the disproportionate exclusion of workers, compare the overview statistics on party exclusions for the period 1962-1971: AJ, 507/XIII, k-30/9, Statistički pregled Saveza komunista Jugoslavije za 1971. godinu, 6. 1.1972. 
In some regions, party patronage was particularly strong - as was the case in the Montenegrin municipalities of Ivangrad and Cetinje, where, according to a 1962 report, even joining the party required the "right connections": "The criteria for admission to the League of Communists are very varied and unclear. [...] Few workers and women are admitted. New members are often admitted through connections and acquaintances or due to certain personal interests." This line then continued in the practical work of the party: "There are significant manifestations of protection - in employment, in the enrichment of individuals at the expense of the community, in child allowances and various social benefits, in job references, unemployment benefits, pensions, etc." ${ }^{\prime 35}$

Opportunistic party entries were often linked to other formal inconsistencies. For example, Veljko Zeković noted at a meeting of the Cadre Commission in 1959 that Montenegro could boast in its statistics about the excellent qualifications of its administrative cadres, but "if you look further, you can see that there is a large proportion of former fighters here who have been awarded a corresponding qualification that they do not actually have." ${ }^{36}$ According to the Cadre Commission, one problem, not only in Montenegro, was also the mass falsification of assessments, which superiors used to help their subordinates get promoted. ${ }^{37}$

The party membership card enabled professional advancement, and advancement in turn enabled manipulation to one's own advantage. This is illustrated by the example of Jakov Popović, director of a trading company in the town of Guča in western Serbia. In his 1973 party expulsion proceedings, he was accused of primarily employing relatives and allowing them to plunder the company, causing damages of over 17 million dinars. The core of the manipulation was that he used accounting tricks to shift operational resources into private hands - for example, by stealing coal that was no longer burned in the company but in employees' households; by diverting building materials with which Popović had allegedly built his own house; by insuring private cars and apartments through the company. In Popović's case, the party remained firm, he was expelled, although in an objection he had described the accusations as being thought

Cf.: AJ, 507/XXX, k. 22, Sednica komisije za razvoj SKJ i kadrovsku politiku, Beograd, 11. 6. 1976, 30.

35 AJ, 507/VIII, K-21: II/4-a-45, Rade Aleksić, Milan Ateljević, Zapažanja o stanju i radu organizacije Saveza komunista u Ivangradskoj i Cetinjskoj opštini, 1. 12.1961.

36 AJ, 507/XIII, K-7/4, Stenografske beleške sa sastanka Komisije za kadrove CK SKJ, 29. 6. 1959, 10-11.

37 AJ, 507/XIII, K-7/4, Informacija o ocenjivanju javnih službenika, 1. 6. 1959, 3. 
up by political opponents; he lost his job and also remained unemployed for a longer period. However, the Popović file also shows the limits of the party's ability to purify itself. The affair also involved Panta Plazinić, Director of the local branch of "Beogradska banka" and also a party member. Plazinić had allowed the company's bank account to be used to illegally divert operating funds for the construction of housing for employees. In 1975, a statutory commission - following further manipulations - also expelled Plazinić, though this decision was soon changed to a "final reprimand." Worthy of mention was the justification, which stated, among other things, "that he is a young person who has also held responsible political positions [...], whose spouse is a member of the League of Communists and comes from a family of active participants in the People's Liberation Struggle [...]." Here, the argument was bluntly based on Plazinić's good connections in the party, which obviously protected him. ${ }^{38}$

One of the peculiarities of the corruption issue under socialism was thus that attention was paid not only to what was done - a significant role in the assessment was also played by the question of who had done something and who had benefited or been harmed. Interesting in this sense is the party expulsion proceedings against the electrician and trade union official Đorđe Pevac from Sremska Mitrovica in 1978. Pevac, like Jakov Popović mentioned above, was accused of a whole series of abuses. Pevac held an executive position in the local paper factory "Matroz" and was accused of both nepotism and personal enrichment. He had provided his own son with an overpriced subcontract for "Matroz"; he had distributed operating resources, in particular coal for heating, to friends and sold some of it; workers of the company, who were entitled to coal from company stocks and were supposed to receive it through the union, had been ignored, and Pevac had forged their signatures on the corresponding receipt lists. Pevac had kept the proceeds from the illegal sale of coal for himself. One of the beneficiaries was of particular interest to the local statutory commission: among the recipients of the embezzled coal was an elderly Orthodox priest; he had apparently been considered because he had once baptized Pevac and because a relative of his was employed by "Matroz". Pevac did not deny the priest's statements before the Statutory Commission, but he insisted that the delivery had been made without his knowledge and that he had, after all, arranged for the priest to pay for it. ${ }^{39}$

38 See the file of Jakov Popović: AS, Đ-2, k. 89, f. 105.

39 See the file of Đorđe Pevac: AS, Đ-2, k. 89, f. 101. 
These examples show that the communist party was willing and able to ensure compliance with formal rules only to a limited extent. This was due, on the one hand, to the formal rules themselves, which became increasingly confusing as workers' self-management was established. The 1974 constitution stipulated that ownership of the means of production was social and that "the working class and socialist society" were responsible for the direct administration of this property. In concrete terms, this meant that responsibilities were strongly decentralized and a correspondingly large group of people in management and self-administration could be tempted to abuse administrative powers. The problem was exacerbated by the lack of clarity as to who owned the social property. The 1974 constitution literally states that "no one has the right of ownership over social means of production" - a formulation that ultimately left open the question of the specific owner and certainly did not make it any easier to defend property titles against local usurpation. ${ }^{40}$

But it was also due to the ideological thought patterns: in the ideological worldview, it was too clear from the outset who had to win, that conformity to the rules itself could not have been placed at the centre. In this respect, the role of the central integration figure, President Josip Broz Tito, is obviously interesting. Numerous letters were sent to Tito's cabinet. They came from veteran comrades complaining vehemently about the decay of mores and wanting to win the head of state as an ally, for example, from Mirko Čakovan from Pančevo, who in 1966 complained to Tito as a "worker and proletarian" that "after liberation the proletariat held power in its hands" but now "in our country the class of petty bourgeoisie has been born." Following the pattern of the good tsar - bad officials, Čakovan wrote: "Around you, too, it seems, there are bureaucrats," people who "have mansions, two cars and a few million in the bank," who "have separated themselves from the people and made themselves so deeply comfortable in armchairs that they no longer see anything except themselves and their sweet lives." Only a radical cleansing could help; a communist party was needed that was "made up of pure proletarians without stains on their vests, without any inclination to enrich themselves and to separate themselves from the masses." ${ }^{\prime 1}$ Tito was considered by many letter

40 Constitution of the Socialist Federal Republic of Yugoslavia, (Beograd, 1974), 67-68; cf. the account of Yugoslav self-governing socialism in: Holm Sundhaussen, Jugoslawien und seine Nachfolgestaaten 1943-2011. Eine ungewöhnliche Geschichte des Gewöhnlichen, (Vienna et al: Böhlau, 2012), 99-112.

41 AS, Đ-2, k. 2, Pismo Mirka Čakovana Titu, 10. 10. 1966. 
writers to be a godlike, righteous judge, who was, however, assumed to be misinformed and therefore needed to be brought to the right understanding. Tito received letters that reported on previously undiscovered, alleged corruption, as well as letters that portrayed ongoing corruption proceedings as unjust and supported by hidden agendas. ${ }^{42}$

The paradox is that Tito himself served as a role model for the "greedy" functionaries - his penchant for a luxurious lifestyle was well known, expressed in lavish receptions, fine clothing, and not least in the decor of his vacation domicile on the Brijuni Islands. ${ }^{43}$ Tito himself often acted beyond the legal process, distributing resources as he saw fit rather than according to established rules. Many petitioners ${ }^{44}$ were asking for concrete goods, housing, jobs, and in some cases for assistance to survive. Tito's cabinet was able to disregard both bureaucratic procedures and the prevailing rules of political correctness, thus creating a network based solely on personal loyalty between certain individuals or groups and the state leadership. ${ }^{45}$ In 1950, in the midst of a period of great ideological rigor and harsh settlements with political opponents, he helped, for example, the bourgeois lawyer Hugo Holzmann from Zagreb, who had made a name for himself in the interwar period by representing foreign capital interests, among other things. When Holzmann, who had lost his real estate holdings in the revolution, complained to Tito about oldage poverty, Tito arranged that 10,000 dinars and 6 kilos of sugar were sent to the sixty-seven year old lawyer. When, during a visit to his native village of Kumrovec in 1952, Tito encountered a peasant who had been

42 See the letters of Nikola Ilić from Leskovac, 11 January 1967; Vladimir Rukavina from Novi Sad, 14 April 1967; a group of "objective communists of Kraljevo", undated; Dragomir Katić from Kraljevo, 18 February 1969; Milisav Jovanović from Požarevac, 10 November 1969. All documents in: AS, Đ-2, k. 4.

43 Marie-Janine Calic stresses that while Tito made ample use of state resources for his own personal comfort, he did not formally acquire wealth, leaving behind "only a small vineyard close to Zagreb". Marie-Janine Calic, Tito. Der ewige Partisan. Eine Biographie, (München: C. H. Beck 2020), 315.

44 The letters and petitions to Tito have become a matter of historiographical interest in the last years. For a broad documentation, cf. Zvonimir Despot, Pisma Titu. Što je narod pisao jugoslavenskom vođi, (Zagreb: Večernji posebni proizvodi, 2010); Josip Mihaljević, Komunizam i čovek. Odnos vlasti i pojedinca u Hrvatskoj od 1958. do 1972, (Zagreb: Hrvatski institut za povijest, 2016).

45 On Tito as a patrimonial ruler in the Weberian sense, see: Marc Živojinović, "Die Sichtbarkeit der Macht. Visualisierung von Herrschaft im sozialistischen Jugoslawien“, Herrschaft in Südosteuropa. Kultur- und sozialwissenschaftliche Perspektiven, eds Mihai-D. Grigore, Radu Harald Dinu, Marc Živojinović, (Göttingen: V\&R Unipress, 2012), 155-174. 
evicted from his home by the police, he instructed the local authorities to find the man a place to live. In the same year, Tito even gave a Dalmatian village the gift of electricity, although the existing regulations stipulated that the villages should finance the connection to the electricity network themselves. Tito's instructions were followed as a matter of course, but at the same time, they caused unrest in the administrative apparatus, which was afraid of precedents. ${ }^{46}$

Not only the party itself, but also Tito could not be an objective judge of the observance of procedures - although the petitioners - as well as the press ${ }^{47}$ - occasionally called him into this role. Of course, it was not possible to address the problem publicly in socialist Yugoslavia; the discussion about it was relegated to political emigration. Here, Tito was partly seen as the head of corruption, as the real problem and a miserable role model, as can be seen, for example, from the undated threatening letter sent from Brussels by Dušan Petrić: "Withdraw honourably and in peace. We know that a few years ago you bought a villa and a yacht on Lake Geneva and that as early as 1966 you had deposited about 7 million francs in Swiss banks. Today this sum is probably much larger. We advise you to retire and spend the rest of your frivolous life on the beautiful beaches of Lake Geneva with Mrs. Jovanka. [...] And don't forget that hardly any dictator has died in bed - especially not in Yugoslavia!"48

Politically intended privilege and abuse converged in veterans' organizations in particular. Since veteran status greatly facilitated access to resources, the archives are full of documents dealing with the connection between earlier contributions (to the party and the partisan movement) and later claims. In this respect, socialist Yugoslavia was hardly different from its "bourgeois" predecessor state - here, too, invoking patriotic merit was commonplace when it came to jobs, real estate, promotions, etc. ${ }^{49}$ In socialist Yugoslavia, the preferential treatment of former partisans was officially sanctioned by a series of legal acts and was also repeatedly legitimized by the central cult of the "people's liberation strug-

46 See the documentation of the aforementioned cases in: AJ, Kancelarija maršala Jugoslavije (836), KMJ II-8/5.

47 See the corruption scandal around the foreign trade manager Bata Todorović in 1976, which caused Tito to give a lengthy interview on illegitimate enrichment in general. Cf. Politika, 1. 2. 1976, 1-3.

48 AS, Đ-2, k.4, Otvoreno pismo drugu Titu, undated, photocopy.

49 Buchenau, "Korruption im ersten Jugoslawien", op. cit;; John Paul Newman, Yugoslavia in the Shadow of the War. Veterans and the Limits of State Building, 1903-1945, (Cambridge: Cambridge University Press, 2015). 
gle". ${ }^{50}$ Nevertheless, the issue also led to tensions, suspicions and accusations. Even veteran Communists viewed the linking of partisan earnings and later privileges with mixed feelings. This became clear at a meeting of the Cadre Commission in April 1959, which discussed the continued employment of former partisans in the civilian sector. Due to a wave of retirements in the army, up to 6,000 people had to be accommodated at short notice, most of whom had no qualifications outside the military, were suffering from war traumas, etc. The head of the commission, Veljko Zeković, set the tone when he demanded that these people, many of them non-commissioned officers, should be qualified for communal leadership posts, in order to stop "negative" tendencies in society: in this way, one obtains an "extraordinary communist [...] who can make mature decisions in his community and oppose certain technocratic and all other proposals of these purely technocratic people." With one word - through the systematic preferential treatment of veterans, the functional differentiation and creeping de-ideologization of the Yugoslav society was to be stopped. Several participants at the meeting opposed this direction. The Montenegrin comrade Neda Božinović warned against imitating the veteran clientelism (solunaštvo) of the first Yugoslavia and thus arousing resentment among the population; Slavko Štrbac (Croatia) reported massive problems with retired (sub)officers who had been retrained in Krajina cities as administrative managers in fast-track courses. The candidates were unqualified, had health problems, and some were alcoholics and thugs. Veljko Zeković became defensive in the course of the discussion, and toward the end could only muster up a wistful response: "We ourselves must do the most to make people stop referring to their merits. Because if we don't give them opportunities, that's the only defence they have. That's a normal thing." He had thus acknowledged partisan meritocracy as a problem, but ultimately located its roots in the lack of resources. ${ }^{51}$

Because the veteran status was attractive, manipulation occurred again and again. Many accusations and investigations against party officials begin with the allegation or statement that the person in question made false statements about his or her role during World War II in order to enjoy privileges. An example of this is the Belgrade lawyer Jovan Čepić,

50 Savez boraca Narodnooslobodilačkog rata Jugoslavije, Rights of war veterans and their organizations in Yugoslavia, (Belgrade: Union of Veterans of the People's Liberation War, 1960).

51 AJ, 507/XIII, K-7/1-9, Stenografske beleške sa sastanka Komisije za kadrove CK SKJ održanog 1. 4.1959, 1.4.1959. 
against whom party expulsion proceedings were opened in 1973. He was accused of having sneaked into the veterans' association SUBNOR ${ }^{52}$ with an embellished biography; neither had he been involved in the people's liberation struggle from the beginning, nor had he been wounded in the war. In 1970, he had been elected chairman of the SUBNOR's housing commission, only to be assigned an apartment himself just one year later. ${ }^{53}$

Another interesting case is the party expulsion proceedings against Slavomir Pokimica in 1978. Pokimica was an official of SUBNOR in Kragujevac and was responsible in particular for housing issues. He was accused of having provided an apartment to a person who had no connection with SUBNOR. Pokimica admitted this before the local statutory commission, but defended himself with reference to his merits and awards since 1941, and reported about his health problems. He was "appalled" by the accusation that he had accepted a bribe for the transaction - which indicates that direct bribery could be far more dishonourable than other accusations. ${ }^{54}$

An affair that shook the SUBNOR of Vojvodina in 1964 can almost be described as a thriller. It came to light through the suicide of accountant Živa Kaluđerski, who in a suicide note reported serious manipulations at the association's headquarters in Novi Sad. Kaluđerski had poisoned himself after state auditors discovered irregularities in SUBNOR's finances and demanded an explanation from Kaluđerski. In the suicide note to his family, Kaluđerski admitted to having issued fictitious invoices for years, for example, in connection with the construction of a war invalids' home. The public funds granted for this purpose had flowed into slush funds, with which three senior officials of the organization had financed luxurious parties, vacations, cars, gifts, etc. Other party functionaries from Novi Sad and Belgrade were also invited to the parties, according to the files of the Statutory Commission. The case apparently ended inconclusively, with cover-ups playing a significant role. Doubts remained about the cause of Kaluđerski's death, especially about the role of a doctor who was suspected of not preventing Kaluđerski's death against his better judgment. With Kaluđerski's death, the most important witness had died, and the SUBNOR was suspected of having destroyed evidence and, in particular, more of Kaluđerski's letters. A court case against the main suspect, Cvetko Topalov, on charges of improper conduct in office and embezzlement

52 Savez udruženja boraca Narodnooslobodilačkog rata (League of the Associations of Veterans of the People's Liberation War).

53 See the Čepić file in: AS, Đ-2, k. 4.

54 See the Pokimica file in: AS, Đ-2, k. 89, f. 111. 
failed because the prosecution was unable to produce any relevant documentation. The court relied mainly on a single expert report, but its author later stated on record that he had been hindered in his work by the police. The leadership of the association was replaced, but one of the accused remained in office and declared that the suspicions were factually unfounded and in fact a campaign of revenge by the new Chairman. ${ }^{55}$

\section{The Problem Turns Outside: Cigarette Smuggling}

Socialist Yugoslavia was a country that relied more than other socialist states on loyalty through liberties and prosperity, and less on manipulation and pressure. But here, too, criticism was only accepted as well-meaning if it came from within and remained intrinsic to the system. People reacted sensitively to external interference, and occasionally the gamut of external threats was played in order to create internal cohesion. These conditions argued strongly against making one's own problems with corruption and criminality the subject of international discussions; such references from abroad were quickly interpreted as an attack and rejected by the Yugoslav press.

Some cases, however, were simply too big to be smoothed over with reference to external "malicious propaganda" - such as that of the freighter "Cavtat" from Dubrovnik, which the Italian financial supervisory authorities tried to stop in the Bay of Naples on January 27, 1970, just as the crew was about to hand over the suspicious cargo to Italian "partners". The captain gave the order to flee, and only after several hours of chase and massive Italian machine gun fire did the "Cavtat" finally surrender 74 miles north of Palermo. Although the crew had already thrown part of their cargo overboard and the hold had caught fire, customs investigators discovered large quantities of smuggled "Marlboro" and "Winston" cigarettes. Italian police rescued the 30-strong crew from the icy Mediterranean, where they had taken refuge from the fire, and took them to a remand centre in Palermo. The Italian press reported on the smuggling case (and especially on how "humanely" the Italian officials had rescued the smugglers from drowning $)^{56}$, triggering a biting reaction in the Yugoslav public - the Belgrade daily Politika defended the seamen and accused

55 See the Živa Kaluđerski file in: AS, Đ-2, k. 4.

56 Cf. "Rimorchiata a Palermo la nave contrabandiera", Corriere della sera, 29. 1. 1970, 19. 
the Italian authorities of a completely exaggerated reaction. ${ }^{57}$ The Yugoslav federal government, however, disagreed behind the scenes. While the crew denied everything before the Italian investigators, the Yugoslav embassy in Rome sent a representative to Palermo to talk to the imprisoned captain, Petar Moretti. The embassy's involvement was portrayed to the Yugoslav public as an effort on behalf of its "own" people, while the explosive details of the conversation remained secret. Moretti confessed that he and his crew had worked with two Neapolitan mafia clans to smuggle cigarettes into Western Europe. The Yugoslavian foreign trade companies "Brodokomerc" and "Prehrana" were involved in the illegal trade, importing Western cigarettes into Yugoslavia, but not putting them on the market there, instead systematically hiring Yugoslavian ship crews to bring the goods to the Western European black market, thus bypassing customs and tax authorities. According to the captain, customs authorities in Yugoslav ports on the Adriatic were also involved in the trade, receiving a share of the revenue for falsifying ship documents. Moretti also referred to "higher authorities" involved in cigarette smuggling. The Belgrade Foreign Ministry distanced itself internally from the "patriotic" portrayal in the Yugoslav press, but also tried to get the ship's crew out of the line of fire, probably to spare Yugoslavia the ignominy of an investigation in a foreign court-the sailors were to be released on a bail of 4 million liras. ${ }^{58}$ However, another source from May 1970 indicates that this plan apparently failed and the "Cavtat" crew was actually tried in Italy. ${ }^{59}$

Internally, the Yugoslav government took the matter very seriously. As early as the beginning of March 1970, the "Trade Subgroup" of the Federal Executive Council (Savezno izvršno veće - SIV) stated that it was a violation of business ethics that was damaging Yugoslavia's reputation and causing great material damage; moreover, the "Cavtat" was not an isolated case. A decision was made to investigate not only the companies and authorities involved, but also their supervisors - Moretti's reference to the "higher authorities" was to be followed up. ${ }^{60}$ However, further investigations revealed nothing on this point in particular, and the impression arises that this moment was brought into play primarily by the sailors them-

57 Rade Vukčević, „Požar izazvali rafali”, Politika, 2. 2. 1970, 4.

58 A, Fond Savezno izvršno veće (130), 731-1187, Informacija u vezi broda „Cavtat”, 9. 3. 1970; Politika, 30. 1.1970, 8.

59 AJ, 130-731-1187, Prikaz Informacije Saveznog javnog tužilaštva o krivičnim postupcima protiv zapovednika i drugih lica zbog nedozvoljene trgovine stranim cigaretama, 21.5.1970.

60 AJ, 130-731-1187, Zaključak u vezi zaplene broda „Cavtat”, 4. 3. 1970. 
selves, who were cagey about their own involvement -as they admitted off the record, partly out of fear of revenge by their Italian "partners, "i.e., the Mafia. Instead, they repeatedly referred to the complicity of Yugoslavian authorities and to "individual socially prominent personalities" who had "known about it and perhaps also participated in the smuggling". ${ }^{61}$

Furthermore, the findings on the scale and mechanisms of smuggling became more concrete. In a letter from the "Trade Subgroup" to the Chairman of the Economic Committee of the Federal Parliament dated June 1,1970 , it was stated that at present, there were practically no ship crews left in Yugoslavia that were not engaged in the purchase and resale of cigarettes and alcohol. The Dubrovnik police calculated that ten ships based here had made a total of 724,000 liras in the years 1968-1969 alone. The foreign trade companies sold the goods to the crews at one-third of the Western European market price, so that the smugglers were able to make an ample profit through resale. To the investigators, however, it was not the sailors who were the main culprits, but rather the foreign trade companies. While it was "only" a matter of illegal extra income for the sailors, the companies systematically stimulated smuggling by running from ship to ship, offering the cigarettes to the crews, and even providing currency credits that the smugglers could repay after successful resale. ${ }^{62}$ There was real competition between the foreign trade companies "Brodokomerc" (Rijeka), "Prehrana" (Ljubljana) and "Dalma" (Split) for the ship crews. ${ }^{63}$

The problems encountered in the fight against this were very similar to those in Western states governed by the rule of law. Formal law may not have been as important in Yugoslavia as it was in Western Europe, but it still made a difference whether certain legal loopholes existed or not. This can be seen clearly in the way the customs authorities dealt with smuggling. The "Cavtat" and other ships had initially obtained their "hot goods" via the port of Rijeka, with customs playing along in line with the aforementioned scheme. Already in the second half of the 1960s, investigators must have known about it, because they increased the pressure on the customs bodies there, whereupon the smuggling shifted to the port of Šibenik. The "Cavtat" crew had contacted the customs officers there as a

61 AJ, 130-731-1187, Prikaz Informacije Saveznog javnog tužilaštva o krivičnim postupcima protiv zapovednika i drugih lica zbog nedozvoljene trgovine stranim cigaretama, 21. 5. 1970, 5.

62 AJ, 130-731-1187, Predsedniku privrednog veća Savezne skupštine, 1. 6. 1970.

63 AJ, 130-731-1187, Prikaz Informacije Saveznog javnog tužilaštva o krivičnim postupcima protiv zapovednika i drugih lica zbog nedozvoljene trgovine stranim cigaretama, 21.5.1970. 
precautionary measure. "Brodokomerc" reacted to the closure of its home port to smuggling by filing a complaint against the local customs branch and won the subsequent court case because the Foreign Trade Act guaranteed the free import and export of goods and there was no legal basis for such customs controls.

In the cases that were uncovered in connection to the Cavtat affair, Yugoslav jurisprudence remained mild, even more so than that of Italy. Only the main organizers of the smuggling on the respective ships were punished, usually the leading crew members. The SIV therefore took it upon itself to tighten the laws. What was needed, according to a May 1970 document of the Yugoslav Federal Prosecutor's Office, was a long-term and systematic campaign "to act on the awareness, on the fight against bad habits and moral deformities among a certain section of our seamen who, by tradition, engage in smuggling." ${ }^{64}$ This passage illuminates the self-image of the prosecutor, who by no means saw himself solely as a mechanical delinquency fighter, but also as an educator who had to work toward changing traditional values and norms.

\section{Conclusion and Outlook}

What were the specifics of the corruption problem in socialist Yugoslavia? What were the continuities and discontinuities in comparison to the interwar or the post-socialist period? These initial questions cannot be answered here conclusively, but they can be answered to some extent. First of all, it is remarkable that the topic of corruption was deeply embedded in the overarching theme of socialist morality. Corruption was not a subject that could have been discussed separately from other problems - from the communists' point of view, everything was always connected with everything else. Corruption, a lack of asceticism, and a lack of communist adherence to principles were closely intertwined in this view and could not be fought separately. This could result in a tendency to ideologize crime, but also to criminalize dissent.

The abuse of office for personal gain was widespread; the archival material on this is extensive and diverse, can be found in various social spheres, and only a very small part of it could be evaluated here. Even comprehensive research, it can be assumed, will make it possible to quantify the phenomenon only in certain places. In any case, the not uncommon practice in socialist Yugoslavia resulted in widespread, sweeping

64 Ibid., 9. 
suspicions - which is a clear parallel to the interwar period as well as to post-socialism. It is true that under socialism, politicians did not use corruption allegations to such an extent as it was practiced before 1941 and after 1989; and current anthropological research on corruption indicates that in that respect, ordinary people remember the 'old order' as less corruption-ridden and more just than the present. ${ }^{65}$ But behind the scenes of socialist Yugoslavia, the issue of illicit personal enrichment was always an important issue. Those accused regularly justified themselves, saying that someone wanted to harm them and to improve their own access to resources by spreading fabricated tales on competitors. Tito's Yugoslavia thus had its own "corruption communication", and it functioned in a specific way: It was predominantly non-public and had a tendency toward the nebulous due to ideological constraints. Last but not least, informal exchanges were condemned most strongly when they were connected to social inequalities between "workers" and "managers". The tension between the upper and the lower strata of socialist society, which has frequently been described in literature ${ }^{66}$, was thus formatted as corruption critique.

But it seems that only in the last decade of Yugoslavia's existence, the country started to depict itself as a society which had fallen prey to managers so powerful that neither the party nor courts could keep their activities in check anymore - this is the impression left by Politika's coverage of the Agrokomerc affair in Bosnia-Hercegovina, where a company had become regionally so important and politically so well-connected that it could issue false promissory notes worth almost 900 million dollars without any effective external checks. By that time, the issue of companies too big and too well-connected to fail became pan-Yugoslav, and the matter was even discussed as a general system failure. ${ }^{67}$ At the same time,

65 Ognjen Kojanić, „You can't weed out corruption. Railway workers' assessment of the state in post-socialist Serbia", Glasnik Etnografskog instituta SANU LXV/1 (2017), 47-63.

66 Cf. Mihajlo Popović, et al., Društveni slojevi i društvena svest, (Beograd: Institut društvenih nauka, 1977); Donald C. Hodges, The Bureaucratization of Socialism, (Amherst: University of Massachusetts Press, 1981); Carl-Ulrik Schierup, "Quasi-Proletarians and a Patriarchal Bureaucracy: Aspects of Yugoslavia's Re-Peripheralisation", Soviet Studies 44/1 (1992), 79-99. - Leonhard Cohen has linked the sensitivity of Yugoslav workers to inequality to the high egalitarian ideals which Yugoslav self-management socialism promised to fulfil. Cf. Leonhard Cohen, "Regional Elites in Socialist Yugoslavia: Changing Patterns of Recruitment and Composition", Leadership selection and patron-client relations in the USSR and Yugoslavia, eds Thomas Rigby, Bohdan Harasymiw, (London etc: Allen\&Unwin, 1983), 98-136.

67 See the coverage of the affair in Politika between 21 August and 31 August 1987. On the widespread failure of late socialist governments to enforce accountability of 
the affair was drawn into the growing national conflicts in Yugoslavia, and even interpreted as an expression of it. ${ }^{68}$ In contrast to earlier scandals, the press played an important role in uncovering the Agrokomerc affair. ${ }^{69}$

Socialist Yugoslavia repeatedly reacted to corruption problems with restructuring measures. In 1957, the Law on Public Employees (Zakon o javnim službenicima) had already introduced the instrument of public tendering, which also provided the opportunity to file a lawsuit against shoddy appointments. In June 1959, the Cadre Committee of the League of Communists was essentially satisfied with the implementation, but admitted that tenders were often regarded as a mere formality and that the candidates were fixed from the outset. ${ }^{70}$

Workers' self-management and the socialist market economy often gave rise to criticism of corruption, especially among the older generation of partisans, some of whom rejected the reforms as an invitation to manipulation. The Yugoslav government reacted here, too, by trying to regulate problematic areas. For example, at the end of the 1960s, it took stronger action against unauthorized price-fixing, especially against local monopolies that tried to insulate themselves from outside competition. In view of the increased entrepreneurial freedom, legal specialists tried to draw an appropriate line between legal profit orientation and unauthorized speculation..$^{71}$ Now that the freedom of economic entities had increased, the problem of contractual compliance was also increasingly addressed. ${ }^{72}$

However, there was a significant systemic limit to the ability to learn - and this was the leadership claim of the League of Communists. Although the League of Communists saw itself per se as an association of non-corrupt people, it functioned de facto as a central rope team through which alone real social advancement could be achieved. This is what made the party so interesting for people who wanted to get ahead materially but

big enterprises (here: shipyards in Pula and Gdansk) see: Peter Wegenschimmel, Zombie-Werftenoder Hungerkünstler? Staatlicher Schiffbau in Osteuropa nach 1970, (Berlin: De Gruyter Oldenbourg, 2021).

68 Admir Mulaosmanović, Bihaćka Krajina 1971.-1991. Utjecaj politike i političkih elita na privredni razvoj, (Sarajevo: Institut za istoriju, 2010), 73-120.

69 Barney Petrovic, "Yugoslav leader quits in financial scandal", The Guardian, 14. 9. 1987, 8.

70 AJ, 507/XIII, K-7-4, Primena konkursa u javnoj službi, 1. 6.1959.

71 AJ 130-731-1187, 0 nekim pojavama nedozvoljenog sporazumevanja, špekulacije u prometu robe i nelojalne utakmice, 12. 5. 1970. See also: "Osnovni zakon o prometu robe", Službeni list 23 (1967) 1,11-16.

72 AJ, 130-731-1187, Neki aktuelni problemi iz oblasti tržišta i prometa robe, 18. 9. 1968. 
had learned to always appear to conform ideologically. It is obvious that no significant impetus against corruption could be expected from such leaders. Transparency, the magic tool of today's anti-corruption fighters, was also hardly applicable under the conditions of one-party rule. It is true that there were cases in which local committees and also the public were able to get a corrupt comrade or manager removed from office. But it was hardly possible to anchor this control systematically and at all levels - such a transparency offensive would have shaken the politically desired power structure too much. When the economic historian Werner Plumpe writes that the communication of corruption often leads to a restructuring of institutions with the aim of curbing corruption, ${ }^{73}$ in socialist Yugoslavia this happened only to a limited extent.

But what did people learn during the socialist period? This text has provided many grounds supporting the view that socialism was indeed a "school of informality" in which people learned to subvert official procedures. However, this finding is not entirely clear. The communist-ascetic ethos, which was in principle hostile to corruption, speaks against it; the same is true for the limited but nevertheless existing learning capacity of the Yugoslav system, which certainly embraced notions of procedural correctness and developed them further; and there are some more indications of anti-corruption consciousness from the archival material which I would like to mention here briefly.

Citizen petitions, such as those received by the Socialist Alliance of the Working People (Socialistički savez radnog naroda - SSRN), are likely to prove interesting and particularly close to the mood of "ordinary people". The Complaints Commission of the Serbian Republic Organization of the SSRN noted in a 1977 report that it had received a total of 108 complaints with more than 700 signatures between January 1976 and June 1977. Foremost these were complaints about "arbitrariness and usurpation of self-management rights." An important point of focus was the water supply, for the establishment of which citizens in many places were asked to pay and, in their own view, were being defrauded by the implementing authorities and companies: "Great is the indignation of the plaintiffs against various manipulations or, to put it mildly, against the lack of accountability for the use of funds collected in the form of citizens' own

73 Werner Plumpe, „Korruption. Annäherung an ein historisches und gesellschaftliches Phänomen", Geld, Geschenke, Politik, eds Jens Ivo Engels, Andreas Fahrmeir, Alexander Nützenadel, (München: Oldenbourg, 2009), (Historische Zeitschrift: Beiheft, N.F. 48), 36. 
contributions." Many complaints referred to "relationships and nepotism, as well as to the intervention of individuals, mostly holders of public functions within the socio-political community. [...] We conclude with a particularly common phrase from complainants: 'I am poor, I have no relatives in power or influential friends, I will probably never find a job.'"74

The Socialist Alliance disagreed about the conclusions citizens drew from their situation. In the report quoted above, it says that above all, people wanted clear rules, even when these rules were not to their advantage: "The working population and citizens wait patiently for a decision where there are self-management agreements or normative acts on the distribution of housing. But they react sharply when the scales and conditions of allocation are not in accordance with the law, or when the procedure for establishing a priority list is not precisely defined."75

This quote suggests that corruption was primarily a problem of the elite and the social superstructure, but did not arise from the desires and values of the population. However, the Socialist Alliance also produced reports suggesting the opposite conclusion. In 1976, for example, the SSRN's community organization in the small southwestern Serbian town of Priboj complained of egoism, belligerence, hatred amongst neighbours, and, above all, a lack of sense of the common good throughout part of the population. Laws are only invoked as long as they are useful, but otherwise the opposite is expected: "When it comes to issuing certificates and other matters, people demand that the responsible authorities and services break laws and regulations. And when you can't get away with such demands, you criticize the services. If we want to enforce the regulations, they threaten and even physically resist." As concrete problem areas, the report mentioned vandalism of buses and facades, insulting and threatening of bus drivers, groundless denunciation of neighbours, various forms of fraud against the state (moonlighting, tax evasion, evasion of social benefits, including by means of false statements about the income situation, fictitious household divisions and divorces, etc.). - "and individuals do all this without any remorse for violating in this way the rights of others who are patiently waiting their turn for employment, housing, assistance, or any other right." While most of the problem areas were typically modern

74 AS, Đ-75, k. 298, Izveštaj o radu Komisije predsedništva RK SSRN Srbije za predstavke i žalbe u periodu januar 1976 - jun 1977 godine, 22. 9. 1977.

75 Ibid, 12.- Other documents come to a similar conclusion, cf. AS, Đ-75, k. 298, Zaključci Izvršnog komiteta Predsedništva CK SKJ o aktuelnim zadacima članova, organizacija i rukovodstava Saveza komunista na rešavanju predloga, predstavki i žalbi, undatet, ca. 1974-1977. 
and strongly reminiscent of complaints from contemporary Western cities, there was another important area where there had already been mass delinquency in 19th century Serbia and the interwar period: land ownership. "[...] since the war, hundreds of hectares of public land have been usurped, especially forests. Recently, land in urbanized areas and on the outskirts of cities has been frequently occupied. [...] Among a significant number of citizens, there is a perception that all social property does not really have an owner and therefore it can be taken and used - and if not, at least ruined." ${ }^{76}$

In view of the contradictory sources, therefore, it is hardly possible to say in general terms what effect socialism had on ideas of the common good. Even the latter, extremely pessimistic report contains passages that point to counterexamples. For example, some villages near Priboj were praised, as a bond for the construction of the Belgrade-Niš highway had yielded a particularly large amount of money. The authors explained the difference with a conceivably general reason: Here, people were committed to the common good because they "live in harmony and good neighbourly understanding".77 Implicitly, this apparently meant a village idyll, which stood out positively from the miserable conditions in the nearby small town - a well-known topos in Southeastern Europe, which is, however, at least in this form, not a fully adequate explanation.

I have only been able to sketch out how social development, ideas of the common good and corruption are actually interrelated. For a more detailed picture, further research is needed. In addition to the discourse and micro level favoured here, macro aspects should also be taken into account, such as the specifics and consequences of Yugoslav workers' self-management and the economic effects of corruption.

\section{Summary}

Socialist Yugoslavia developed, as other real socialist states did, a specific understanding of corruption, which was less technical than in liberal-capitalist societies and more intensively tied to morale and ideology. While a good communist was supposed to be non-corrupt by definition, functionaries could use a taintless political reputation for obtaining material gains, especially in the housing sector and on the job "market".

76 AS, Đ-75, k. 298, Opštinska Konferencija SSRN Priboj: Analiza o postupcima i ponašanjima pojedinih građana u ostvarivanju prava i obaveza, Decembar 1976.

77 Ibid., 11. 
Corrupt practices, as it seems, were less monetarized than in interwar Yugoslavia and rather concentrated on non-monetary exchanges. During its early years, socialist Yugoslavia was proud of applying extremely hard measures even against petty corruption, but this vigour waned as the system became more liberal. Mature Yugoslav socialism offered ample opportunities for self-enrichment especially for higher ranking members of the League of Communists, though this enrichment was, by standards of both pre- and post-socialist realities, still rather modest. Yugoslav anti-corruption campaigns were only occasional and careful not to discredit the most high-ranking institutions of the state, including state president Josip Broz Tito. Though this article does not include a systematic monitoring of the Yugoslav press on the corruption issue, it is clear that anti-corruption was not driven by civil society but was rather an expression of frictions within elite groups which occasionally battled each other by claiming the corruption of the respective others. All in all, socialist Yugoslavia should neither be labelled as a "school of corruption" responsible for post-socialist corruption, nor was it an example for sustainable anti-corruption.

\section{Sources and Literature}

- Arhiv Srbije: Fond Đ-2, Savez komunista Srbije; Fond Đ-75, Republička konferencija SSRN Srbije.

- Arhiv Jugoslavije: Fond 836, Kancelarija maršala Jugoslavije; Fond 130, Savezno izvršno veće; Fond 507, Savez komunista Jugoslavije; Fond 49, Ministarstvo pravosuđa Vlade FNRJ.

- $\quad$ Constitution of the Socialist Federal Republic of Yugoslavia. Belgrade, 1974.

- Das Jugoslawische Strafgesetzbuch vom 2. März 1951, In deutscher Übertragung mit einer Einführung von Dr. August Munda. Berlin, 1952.

- Krivični zakon Socijalističke Federativne Jugoslavije. Zagreb, 1982.

- Osnovni zakon o prometu robe. Službeni list 23 (1967), 1,11-16.

- Savez boraca Narodnooslobodilačkog rata Jugoslavije. Rights of war veterans and their organizations in Yugoslavia. Belgrade: Union of Veterans of the People's Liberation War, 1960.

- Zakon o krivičnim delima protiv opštenarodne imovine i imovine zadružnih i drugih društvenih organizacija. Službeni list 4 (1948), 87, 1365-1366.

- Zakon o suzbijanju nedopuštene spekulacije i privredne sabotaže. Službeni list 1 (1945), 26.

- Zakon o suzbijanju nedopuštene trgovine, nedopuštene špekulacije i privredne sabotaže. Službeni list 2 (1946), 56.

- Zakon o zaštiti narodnih dobara i njihovom upravljanju. Službeni list 1 (1945), 36, 296. 
- Buchenau, Klaus. „Korruption im ersten Jugoslawien (1918-1941). Eine Skizze zu Diskurs und Praxis“. Südost-Forschungen 72 (2013), 130-164.

- $\quad$ Calic, Marie-Janine. Tito. Der ewige Partisan. Eine Biographie. München: C. H. Beck, 2020.

- $\quad$ Cohen, Leonhard. „Regional Elites in Socialist Yugoslavia: Changing Patterns of Recruitment and Composition". Leadership selection and patron-client relations in the USSR and Yugoslavia, eds Thomas Rigby, Bohdan Harasymiw, 98-136. London etc: Allen\&Unwin, 1983.

- $\quad$ Cvetković, Srđan. “Afera 'Granap' - smrtna kazna zbog korupcije”. Korupcija i razvoj moderne srpske države, ur. Aleksandra Bulatović, Srđan Korać, 143150. Beograd: Centar za menadžment, 2006. (cyrillic)

- $\quad$ Despot, Zvonimir. Pisma Titu. Što je narod pisao jugoslavenskom vođi. Zagreb: Večernji posebni proizvodi, 2010.

- $\quad$ Hodges, Donald C. The Bureaucratization of Socialism. Amherst: University of Massachusetts Press, 1981.

- Kanzleiter, Boris. Die "Rote Universität". Studentenbewegung und Linksopposition in Belgrad 1964 -1975. Hamburg: VSA Verlag, 2011.

- Kojanić, Ognjen. „You can't weed out corruption. Railway workers' assessment of the state in post-socialist Serbia”. Glasnik Etnografskog instituta SANU LXV/1 (2017), 47-63. doi: 10.2298/GEI1701047K

- Marinković, Aleksandar Đ. „Uništenje srpske privredne elite posle Drugog svetskog rata - Primer porodice Teokarović“. Istorija 20. veka 2/2010, 135148.

- Mihaljević, Josip. Komunizam i čovek. Odnos vlasti i pojedinca u Hrvatskoj od 1958. do 1972. Zagreb: Hrvatski institut za povijest, 2016.

- Mulaosmanović, Admir. Bihaćka Krajina 1971-1991. Utjecaj politike i političkih elita na privredni razvoj. Sarajevo: Institut za istoriju, 2010.

- Newman, John Paul. Yugoslavia in the Shadow of the War. Veterans and the Limits of State Building, 1903-1945. Cambridge: Cambridge University Press, 2015.

- Olson, Mancur. Power and prosperity. Outgrowing communist and capitalist dictatorships. New York: Basic Books, 2000.

- $\quad$ Plumpe, Werner. „Korruption. Annäherung an ein historisches und gesellschaftliches Phänomen“. Geld, Geschenke, Politik, eds Jens Ivo Engels, Andreas Fahrmeir, Alexander Nützenadel, 19-47. München: Oldenbourg, 2009 (Historische Zeitschrift: Beiheft, N.F. 48).

- $\quad$ Popović, Mihajlo et al. Društveni slojevi i društvena svest. Beograd: Institut društvenih nauka, 1977.

- Sandholtz, Wayne, Rein Taagepera. "Corruption, Culture and Communism". International Review of Sociology 15/1 (2005), 109-131. doi: 10.1080/03906700500038678 
- Schierup, Carl-Ulrik. "Quasi-Proletarians and a Patriarchal Bureaucracy: Aspects of Yugoslavia's Re-Peripheralisation". Soviet Studies 44/1 (1992), 79-99. doi: 10.1080/09668139208411995

- $\quad$ Shleifer, Andrei, Robert W. Vishny. "Corruption”. The Quarterly Journal of Economics 108/3 (1993), 599-617.

- Sundhaussen, Holm. Jugoslawien und seine Nachfolgestaaten 1943-2011. Eine ungewöhnliche Geschichte des Gewöhnlichen. Vienna et al: Böhlau, 2012.

- Volkov, Vadim. Violent entrepreneurs. The use offorce in the making of Russian capitalism. Ithaca: Cornell University Press, 2002.

- Von Halem, Friedrich. „Eine Skizze über Gesetz und Wertordnung in Ost und West: Von der Antike bis zur Moderne“. Forum für osteuropäische Ideen- und Zeitgeschichte 7 (1) 2003, 15-51.

- $\quad$ Wagner, Patrick. Bauern, Junker und Beamte. Lokale Herrschaft und Partizipation im Ostelbien des 19. Jahrhunderts. Göttingen: Wallstein-Verlag, 2005.

- Weber, Max. Wirtschaft und Gesellschaft. Tübingen: Mohr, 1922.

- Wegenschimmel, Peter. Zombie-Werften oder Hungerkünstler? Staatlicher Schiffbau in Osteuropa nach 1970. Berlin: De Gruyter Oldenbourg, 2021.

- Živojinović, Marc. „Die Sichtbarkeit der Macht. Visualisierung von Herrschaft im sozialistischen Jugoslawien". Herrschaft in Südosteuropa. Kultur- und sozialwissenschaftliche Perspektiven, eds Mihai-D. Grigore, Radu Harald Dinu, Marc Živojinović, 155-174. Göttingen: V\&R Unipress, 2012.

- Corriere della sera

- Politika (cyrillic)

- The Guardian 


\title{
Резиме
}

\section{Клаус Бухенау}

\section{Трећи пут у сумрак? Корупција у социјалистичкој Југославији}

\begin{abstract}
АпстРАКт: Корупција у социјалистичкој Југославији била је специфична појава у поређењу с међуратним периодом или постсоцијализмом. За разлику од либерализма, комунистичка идеологија није подржавала схватање корупције као засебног проблема, већ је најчешће посматрала политичке и материјалне „девијације“ као да потичу из истог извора - тј. из непостојања политичког морала. Савез комуниста није успео да испуни улогу друштвеног просветитеља, будући да је био заглављен између декларативне моралне ригидности и чињенице да се материјалне потребе и похлепа најбоље могу задовољити чланством у партији.

КљУчнЕ РЕчи: корупција, Југославија, Србија, комунизам, клијентелизам
\end{abstract}

Социјалистичка Југославија је, попут других социјалистичких држава, развила специфично схватање корупције, које је било мање техничко него у либерално-капиталистичким друштвима и чвршће везано за морал и идеологију. Док је добар комуниста по дефиницији требало да буде некорумпиран, функционери су могли да користе неокаљану политичку репутацију за стицање материјалне користи, посебно у стамбеном сектору и на „тржишту“ рада. Корупција је, чини се, била мање монетаризована него у међуратној Југославији и више концентрисана на немонетарну размену. У свом раном периоду, социјалистичка Југославија дичила се применом изузетно оштрих мера чак и за ситну корупцију, али је та оштрина опадала како је систем постајао либералнији. Зрели југословенски социјализам пружао је широке могућности за лично богаћење, посебно за чланове Савеза комуниста на вишим положајима, иако је то богаћење, према стандардима и предсоцијалистичке и постсоцијалистичке реалности, ипак било прилично скромно. Југословенске антикорупционашке кампање биле су нередовне и водило се рачуна да не дискредитују највише државне институције, укључујући председ- 
ника државе Јосипа Броза Тита. Иако овај чланак није подразумевао систематско праћење југословенске штампе по питању корупције, јасно је да борбу против корупције није покретала друштвена база, већ да је она била одраз трвења различитих група елита које би се повремено сукобљавале, тврдећи да корупција потиче из супротног табора. Коначно, социјалистичку Југославију не би требало називати „школом корупционаштва” одговорном за постсоцијалистичку корупцију, нити је она била пример одрживе борбе против корупције. 